\title{
Emerging Entrepreneurial and Business Planning Competencies Required By Motor Vehicle Mechanic Students in Establishing Entreprise in Bauchi and Gombe States, Nigeria
}

\author{
Dawha Josephine Musa (M.Tech.Ed.) \\ Department of Technical Education \\ Federal College of Education (Technical) Gombe \\ jolerfred@yahoo.com
}

\author{
J. D. Medugu (Ph.D) \\ Department of Technology Education \\ Modibbo Adama University of Technology Yola \\ jdmedugu2010@yahoo.com
}

\begin{abstract}
The purpose of the study was to investigate the perceived emerging entrepreneurial and business planning competencies in establishing automobile enterprise required by MVM students in technical colleges in Bauchi and Gombe states of North Eastern Nigeria. The study adopted a descriptive survey research design. The population of the study was 265 consisting of 96 automobile technology teachers and 169 automobile technology entrepreneurs. The study was guided by two research questions and two hypotheses were formulated and tested at 0.05 level of significance. The instrument used for the study was a structured questionnaire which was face and content validated by three experts. Cronbach Alpha reliability method was adopted to determine the internal consistency of the instrument which yielded a reliability coefficient of 0.90. The data collected were analyzed using mean, standard deviation and t-test. It was found out that 15 emerging entrepreneurial competencies and 13 business planning competencies were perceived to be required by MVM students.It was recommended among others thatthe teaching staff of technical colleges should be exposed to adequate training and retraining on the emerging automobile technology entrepreneurialskills and competencies and the new contents of automobile technology to be included in to the curriculum of technical colleges.
\end{abstract}

Keywords: Motor Vehicle Mechanics Trades, Entrepreneurial, Entrepreneurial competencies, Business Planning Competencies, Small and Medium Scale Enterprise.

\section{INTRODUCTION}

Technical and Vocational Education and Training (TVET) programmes are offered for the purpose of producing skilled manpower required for the nation's economic and technological development (Federal Republic of Nigeria [FRN], 2004). In the Nigerian educational system, Motor Vehicle Mechanics(MVM) trades is one of the TVET programmes in technical colleges in which students are examined by the National Business and Technical Examination Board (NABTEB) based on the National Board for Technical Education (NBTE) curriculum for the award of National Technical Certificate (NTC) and Advance National Technical Certificate (ANTC) (NBTE, 2001).The MVM programme is designed to produce competent craftsmen and technicians which according to the NBTE curriculum are expected to test, diagnose, service and completely repair any fault relating to the automobile assembly main units and systems to the manufacturers' specification. The various sections include motor vehicle repair, vehicle body repair, auto electricity and vehicle body painting. After graduation, the competencies acquired will enable the students create or secure sustainable jobs and use their knowledge, abilities, initiative and creativity for self-reliance (Adamu, Dawha \& Kamar, 2015).

FRN (2004) pointed out that the main feature of the curricular activities for technical colleges is structured in foundation and trade modules; the curriculum for each trade consists of general education, theory and related courses, workshop practice, industrial training components and small business management. The MVM trade theory and workshop practice cover the major automobile assembly main units and systems, their functions and principles of operation. This curriculum, if adequately implemented, is expected to produce competent craftsmen in Motor Vehicle Mechanics for industrial and technological development in Nigeria. Such craftsmen if they possess adequate competencies can be employable or be self-reliant and enterprising.

These attributes enable one to plan business activities to the growth and sustenance of the business. Howell (2005) stated that a good entrepreneur must possess the ability to plan, manage and organize 
business effectively. However with the rapid changes in automobile technology as well as social and economic changes of today have changed the job demands of automobile craftsmen making them unemployable or ill fitted for the demands of the jobs market (Legbara \& Mbah, 2009). Following the influx of sophisticated cars into the country from different parts of the world, there is the need for special training to equip the mechanics with modern skills for handling the vehicles properly. The knowledge of the training would enhance their skills and encourage specialization and competition in the trade. Said that "the training is not limited to specific vehicles but comprise all sophisticated vehicles,'. The application of modern tools had been assisting in the repair of the wheels of cars with sophisticated technologies as detecting problems in modern cars is increasingly becoming impossible for many of mechanics because of their lack of computer knowledge.

If automobile technology craftsmen are therefore trained in entrepreneurship, they can become entrepreneurs. However, most of these students are graduating from technical colleges without the necessary skills and entrepreneurial competencies. Furthermore many of these students do not possess entrepreneurial skills that will enable them plan, establish and manage a small business enterprise so as to become self-employed and self-reliant on graduation (Okoli, 2009). Thus, resulting in massive unemployment of technical college automobile graduates there is the need for every Nigerian youth to strive for self-reliance through self-employment. Aina (2008) observed that National Policy on Education (FRN, 2004) stated goals with respect to automobile technology are yet to be achieved due to lack of the necessary practical skills and entrepreneurial competencies that will enable them handle new technologies and to be self-employed. The high rate of unemployment among the technical college students has been attributed to lack of competencies required in the world of work. Ifedi (2009) in his reaction agrees that one of the main causes of unemployment among college students is lack of employable skills. Thus, we are faced with the burdens of surplus unemployable manpower as a result of the wide gap created by absence of entrepreneurial competencies by the Automobile Technology students. This calls for the acquisition of entrepreneurial skills which is a prerequisite for any meaningful self-employment. Hence, this study, to identify emerging entrepreneurial and business planning competencies required in establishing and running small and medium scale enterprises by MVM students in Gombe and Bauchi States.

\subsection{Research Question}

The following two research questions were answered to guide this study:

1. What are the emerging entrepreneurial competencies required by MVM students in establishing an automobile enterprise?

2. What are the businesses planning competencies required in establishing and running an automobile enterprise by MVM students?

\subsection{Hypotheses}

The following two null hypotheseswere tested at 0.05 level of significance:

- There is no significant difference between the mean responses of MVM teachers and entrepreneurs on the emerging entrepreneurial competencies required by MVM students in establishing an automobile enterprise.

- There is no significance difference between the mean responses of MVM teachers and entrepreneurs on the business planning competenciesrequired in establishing automobile enterprise by MVM students.

\section{Methodology}

The study adopted a descriptive survey design. Descriptive survey research, according to Nworgu (2006) is a systematic means of data collection. Descriptive survey research design was considered suitable for the study because the study solicited for information from the sampled respondents and the findings were generalized on the whole population. The study was carried out in technical colleges in Gombe and Bauchi States which is located in North-Eastern part of Nigeria. The population of the study was 265 made up of 96 MVM teachers and 169 automobile technology entrepreneurs in Gombe and Bauchi States. The entire population was involved in the study because of its manageable size.

A structured questionnaire containing 28 items developed by the researchers from literature reviewed were used for data collection from the respondents. The instrument was divided into sections, A and 
Emerging Entrepreneurial and Business Planning Competencies Required by Motor Vehicle Mechanic Students in Establishing Entreprise in Bauchi and Gombe States, Nigeria

B. A was designed to obtain pertinent background and personal data of the respondents, B was designed to obtain information from the MVM teachers and entrepreneurs on emerging entrepreneurial competencies required of MVM students in establishing an automobile enterprise. A five point scale of Highly required (HR), Required (R), Moderately Required (MR), Not-Required (NR), Highly Not-Required (HNR), were written against each item with a corresponding assigned values of $5,4,3,2$, and 1 respectively.

The instrument was face and content validated by three experts from the Department of Technology Education, Modibbo Adama University of Technology, Yola. Cronbach Alpha reliability method was adopted to determine the internal consistency of the instrument. A reliability coefficient of 0.90 was obtained. The questionnaires were administered by the researcher with the help of two research assistants. The respondents were allowed a period of two weeks, after which the researcher and the research assistants went round to collect the questionnaire items for analysis.

The data collected were analyzed using mean and t-test. The grand mean of items were used to answer the research questions, while the t-test statistics was employed to test the null hypotheses. Hypotheses were accepted if the test statistics is in the critical region and rejected if it is not in the critical region while an item was accepted as a required competency, if the calculated grand mean of that item is greater or equal to 3.00 while mean of any item below 3.00 was considered as not required.

\section{RESUlts}

\subsection{Research Question 1}

What are the emerging entrepreneurial competencies required by MVM students in establishing an automobile enterprise?

Table1. Mean Rating of Respondents on the Emerging Entrepreneurial Competencies Required by MVM Students in Establishing an Automobile Enterprise

\begin{tabular}{|l|l|l|l|l|l|}
\hline S/N. & Emerging Entrepreneurial Competencies & $\overline{\mathbf{X}}_{\mathrm{T}}$ & $\overline{\mathbf{X}}_{\mathrm{E}}$ & $\overline{\mathbf{X}}_{\mathrm{G}}$ & Remark \\
\hline 1. & Select appropriate tool for maintenance operation & 3.44 & 4.20 & 3.92 & required \\
\hline 2. & Use on-board diagnostic tools (OBD/OBD II) & 2.16 & 4.23 & 3.84 & required \\
\hline 3. & Locate data cable port for OBD/OBD II & 3.10 & 4.30 & 3.87 & required \\
\hline 4. & $\begin{array}{l}\text { Identify the different types of engine ignition system e.g. breaker less or } \\
\text { distributor less }\end{array}$ & 3.17 & 4.26 & 3.87 & required \\
\hline 5. & Identify the electrical symbols of working drawing of vehicles & 3.25 & 4.31 & 3.93 & required \\
\hline 6. & Identify faulty sensor(s) on the vehicle after using the scanning tool & 3.19 & 4.42 & 3.97 & required \\
\hline 7. & Identify faulty actuator(s) on the vehicle after using the scanning tool & 3.20 & 4.38 & 3.95 & required \\
\hline 8. & Interpret fault codes on a diagnostic tool & 3.02 & 4.42 & 3.91 & required \\
\hline 9. & Understand how to use digital wheel balancing machine & 3.37 & 4.47 & 4.07 & required \\
\hline 10. & Understand how to use digital wheel alignment machine & 3.71 & 4.33 & 4.11 & required \\
\hline 11. & $\begin{array}{l}\text { Rectify faults on the engine management system (combined fuel and } \\
\text { ignition system) }\end{array}$ & 3.46 & 4.33 & 4.01 & required \\
\hline 12. & Diagnose and service a faulty injector nozzle & 3.22 & 4.33 & 3.93 & required \\
\hline 13. & $\begin{array}{l}\text { Understand how to update various software used on the vehicle electronic } \\
\text { control unit (ECU) }\end{array}$ & 2.09 & 4.43 & 3.58 & required \\
\hline 14. & Locate and rectify faults on electronic control unit (ECU) & 2.48 & 4.38 & 3.69 & required \\
\hline 15. & $\begin{array}{l}\text { Observe the necessary safety rules and regulations during motor vehicle } \\
\text { maintenance operation }\end{array}$ & 2.44 & 4.35 & 3.66 & required \\
\hline
\end{tabular}

Result in Table 1 revealed that both MVM teachers and automobile technology entrepreneurs agreed that all the emerging entrepreneurial competencies are required for establishing an Automobile enterprise. They had their grand total mean $\left(\overline{\mathbf{X}}_{\mathrm{G}}\right)$ rating ranging from 3.58 to 4.11 which is above the cut off mark of 3.00 .

\subsection{Research Question 2}

What are the businesses planning competencies required in establishing automobile enterprise by MVM students? 
Table2. Mean Rating of Respondents on business planning competencies required in establishing automobile enterprise by MVM students

\begin{tabular}{|l|l|l|l|l|l|}
\hline S/n. & Business Planning Competencies & $\overline{\mathbf{X}}_{\mathrm{T}}$ & $\overline{\mathbf{X}}_{\mathrm{E}}$ & $\overline{\mathbf{X}}_{\mathrm{G}}$ & Remark \\
\hline 16. & $\begin{array}{l}\text { Good knowledge base that enable MVM students to } \\
\text { define automobile enterprise }\end{array}$ & 4.33 & 4.33 & 4.33 & required \\
\hline 17. & $\begin{array}{l}\text { knowledge on how to bring together a unique combination of resources to } \\
\text { exploit an opportunity }\end{array}$ & 3.68 & 4.04 & 3.81 & required \\
\hline 18. & Enables MVM students to set reasonable and measurable goals & 3.89 & 3.95 & 3.91 & required \\
\hline 19. & Enables MVM students to be committed towards goal & 4.12 & 4.32 & 4.19 & required \\
\hline 20. & $\begin{array}{l}\text { Enables MVM students to carefully think through every } \\
\text { aspect of enterprise purpose }\end{array}$ & 3.46 & 3.82 & 3.62 & required \\
\hline 21. & $\begin{array}{l}\text { Enables MVM students to prepare workable business plan in order to } \\
\text { establish creditability with potential employees, suppliers and clients }\end{array}$ & 3.21 & 3.05 & 3.15 & required \\
\hline 22. & To acts as part of the on-going process of strategic Planning & 4.00 & 3.84 & 3.94 & required \\
\hline 23. & Enables MVM students to estimate for business demands & 4.42 & 4.58 & 4.48 & required \\
\hline 24. & $\begin{array}{l}\text { Enables MVM students to be imaginative and creative in taking calculated } \\
\text { risks }\end{array}$ & 3.98 & 4.02 & 3.99 & required \\
\hline 25. & $\begin{array}{l}\text { Enables MVM students to cope with changing and emerging automobile } \\
\text { technology }\end{array}$ & 3.02 & 3.00 & 3.01 & required \\
\hline 26. & $\begin{array}{l}\text { Enables MVM students to manage time to meet job } \\
\text { schedule }\end{array}$ & 3.93 & 3.19 & 3.66 & required \\
\hline 27. & Enables MVM students to make use of appropriate business feedback & 3.34 & 3.94 & 3.56 & required \\
\hline 28. & $\begin{array}{l}\text { Enables MVM students to detect errors on time, block leakages and prevent } \\
\text { wastage }\end{array}$ & 4.01 & 3.75 & 3.91 & required \\
\hline
\end{tabular}

Results from Table 3 revealed that the grand mean scores $\left(\overline{\mathbf{X}}_{\mathrm{G}}\right)$ of the respondents ranged from 3.00 to 4.75. All the items had their mean scores $(\overline{\mathbf{X}})$ above the cut-off point of 3.00 , implying that the respondents considered all the items on business planning as competencies required by MVM students in establishing and running automobile enterprise.

\subsection{Hypothesis 1}

There is no significant difference between the mean responses of MVM teachers and entrepreneurs on the emerging entrepreneurial competencies required by MVM students in establishing an automobile enterprise.

Table3. T-Test Analysis of MVM Teachers and Automobile Entrepreneurs on Emerging Competencies Required by MVM Students in Establishing an Automobile Enterprise

\begin{tabular}{|l|l|l|l|l|l|l|l|}
\hline Respondents & $\mathrm{N}$ & \multicolumn{1}{|c|}{$\overline{\mathbf{X}}$} & $\delta$ & $\mathrm{df}$ & t-cal & t-crit & Remark \\
\hline MVM Teachers & 96 & 3.09 & 0.431 & & & & \\
\hline & & & & 263 & -11.12 & 1.968 & accepted \\
\hline Automobile Entrepreneurs & 169 & 4.34 & 0.076 & & & & \\
\hline
\end{tabular}

The analysis in Table 2 shows that the calculated value of $\mathrm{z}$ which is -11.09 is less than critical value of $\mathrm{z}$ which is 1.96 . Thus, the null hypothesis was accepted and the alternative hypothesis rejected. Therefore, there is no significant difference between the mean responses of MVM teachers and entrepreneurs on the emerging competencies required by MVM students in establishing an automobile enterprise.

\subsection{Hypothesis 2}

There is no significance difference between the mean responses of MVM teachers and entrepreneurs on the business planning competencies required in establishing and running an automobile enterprise by MVM students.

Table4. T-test Analysis of Mean Ratings of MVM teachers and entrepreneurs on the business planning competencies required in establishing and running an automobile enterprise by MVM students

\begin{tabular}{|l|l|c|l|l|l|l|l|}
\hline Respondents & $\mathrm{N}$ & $\overline{\mathbf{X}}$ & $\delta$ & $\mathrm{df}$ & t-cal & t-crit & Remark \\
\hline MVM Teachers & 96 & 3.80 & 0.428 & & & & \\
\hline & & & & 263 & -0.298 & 1.968 & accepted \\
\hline Automobile Entrepreneurs & 169 & 3.85 & 0.491 & & & & \\
\hline
\end{tabular}


Table 4 shows that MVM teachers recorded a mean score $(\overline{\mathrm{X}})$ of 3.80 and also Automobile entrepreneurs recorded a mean score $(\overline{\mathrm{X}})$ of 3.85 . The $\mathrm{t}$-calculated value of -0.298 is lower than $\mathrm{t}$ tabulated value of 1.96, indicating that the null hypothesis was accepted and the alternative hypothesis rejected. Thus, no significance difference existed between the mean responses of MVM teachers and entrepreneurs on the business planning competencies required in establishing and running an automobile enterprise by MVM students.

\section{DisCUSSION}

The finding of this study revealed that MVM students need emerging entrepreneurial competencies to establish automobile enterprise after graduation. This finding in agreement with the finding of Essien (1996) who found out that most of the technical graduates are deficient in new methods related to their areas of specialization. The study also revealed 13 business planning competencies that will help students to exhibit creativity, imbibe business ethics, attitude, behaviour and other entrepreneurial skills needed for self-reliance and self-employment. This is in line with the findings of Okolocha and Ile (2012) who stated business plan strategy were strongly considered as helpful in teaching entrepreneurship to student to enable the students be self-reliance. They maintain that when teachers apply well developed business plan in their teaching, the students will grasp the overall picture of the what? why? how? where? And when? associated with entrepreneurship ventures. These competencies will enable students deal with the new automobile technologies and set up businesses of their choice, remain in businesses after graduation and contribute their quota to the economic development of the country.

The t-test analysis for hypothesis 1 revealed that there was no significant difference between the mean responses of Automobile Technology teachers and entrepreneurs on the emerging competencies required by MVM students in establishing an automobile enterprise. The non-significant difference between the mean responses of the two groups of respondents may be attributed to the fact that a good knowledge of modern practices and trends is an invaluable asset in the entrepreneur's toolkit. This is in conformity with the finding of Miller (2006) and Okoli (2009) who revealed that Automobile Technicians lack the necessary skill and knowledge needed to effectively carry out maintenance and repairs operation on vehicles.

The t-test analysis for hypothesis 2 revealed that there was no significant difference between the mean responses of Automobile Technology teachers and entrepreneurs on the business planning competencies required by MVM students in establishing an automobile enterprise. This is evident from the table since the $t$-calculated value of -0.298 is less than the t-tabulated value of 1.968 at five percent level of significance.

\section{Conclusion}

As revealed by the findings of this study, both the MVM Teachers and automobile entrepreneurs viewed most of the technical competencies items under emerging entrepreneurial competencies as required by MVM students before graduation. Hence, there is need to expose the MVM teachers in Bauchi and Gombe states on the emerging competencies through regular workshops and seminars.

\section{RECOMMENDATIONS}

Based on the findings of the study, the following recommendations were made:

- Government, employers of technical college graduates in the society should provide modern tools and equipment to technical colleges for effective training of students of automobile technology.

- The teaching staff of technical colleges should be exposed to adequate training and retraining on the entrepreneurial skills and competencies and the new contents of automobile technology to be included in to the curriculum of technical colleges.

- MVM teachers should use business planning strategies as entrepreneurship driven instructional method which is capable of enhancing acquisition of entrepreneurial competencies. 


\section{REFERENCES}

Adamu, G. G., Dawha, J. M. \&Kamar, T. S. (2015). Development and validation of mechanical engineering trade skills assessment instrument for sustainable job security in Yobe state. Journal of Art and Science Education Research (JASER), 2(1) pp 1-9. Retrieved from http//:www. ijvocter.com.

Aina, O. (2008). Relevance of secondary education business and technical qualifications as admission requirements into tertiary institution.Journal of Vocational Technical Education, 2(2), 14-21.

Essien, E.E. (1996). An Evaluation of Technical Education Programmes in Secondary School in Akwalbom State. An Unpublished M.Ed Thesis. Department of Vocational Teacher Education, University of Nigeria, Nsukka

Federal Republic of Nigeria (FRN) (2004).National policy on education, Lagos: NERDC Press.

Ifedi, C. (2009). “Manpower Development Job Opportunities” Business Times, May 22, 24.

Miller, C. B. (2006). Selecting young workers. The influence of applicants' education and skills on employability assessment by Employers Columbus national center for research in vocational education, the Ohio State University Press.

National Board for Technical Education (NBTE), (2001).National technical certificate examination (craft level) syllabus for engineering trades based on the NBTE modular curricular. Kaduna: NBTE Press

Nwokolo, P. O. (2009) Entrepreneurship in Technology Education in Entrepreneurship practices in Education. Immunize: Research and publication unit.

Nworgu, B. G. (2006). Educationa 1Research: Basic issues and Methodology. Nsukka, University Trust Publishers.

Okoli, H. J. (2009). Preparedness of STM teachers to develop entrepreneurial skills in secondary school students through STM Education. A proceedings of Science Teachers Association of Nigeria. $50^{\text {th }}$ Annual Conference, held $22^{\text {nd }}-25^{\text {th }}$ Sept. at Federal Polytechnic. Offa 2009.

Okolocha, C. C. \& Ile, C. M. (2012).Strengths of the Business Plan and Industrial Collaboration Strategies in the Teaching of Entrepreneurship in Tertiary Institutions in Anambra State, Nigeria. An International Journal of Arts and Humanities: AFRREV IJAH Vol. 1 (2). Retrieved 17 January, 2015 from http://www.afrrevjo.net/afrrevijah

\section{AUTHORS' BIOGRAPHY}

$\begin{array}{ll}\text { Name } & - \text { Dawha. Josephine Musa } \\ \text { Date of birth and place of birth } & -1978, \text { Gombe } \\ \text { Sex } & - \text { Female } \\ \text { Marital status } & - \text { Married } \\ \text { Address } & \text { - Despartment of Technical Education Federal College of Education } \\ & \text { (Technical) Gombe } \\ & \\ \text { Name } & - \text { Medugu, Jimritu Dunama } \\ \text { Date of birth and place of birth } & -1963, \text { Duhu, Madagali L.G.A. } \\ \text { Sex } & - \text { Male } \\ \text { Marital status } & \text { - Married } \\ \text { Address } & - \text { Department of Electrical Technology Education, Modibbo Adama } \\ & \text { University of Technology, Yola }\end{array}$

